\title{
REGIONAL PLANNING AND DEVELOPMENT BASED ON DISASTER RISK REDUCTION IN BANTEN PROVINCE
}

\section{PERENCANAAN DAN PENGEMBANGAN WILAYAH BERBASIS PENGURANGAN RISIKO BENCANA DI PROVINSI BANTEN}

\author{
Novian Andri Akhirianto ${ }^{1}$ \\ ${ }^{1}$ Pusat Teknologi Reduksi Risiko Bencana - BPPT, Geostech 820 Puspiptek Serpong \\ e-mail: novian.bppt@gmail.com
}

\begin{abstract}
Banten Province is one of the areas prone to disaster, because it has various hazards of disaster. On the other side, the process of regional development continues as well as all human activities. To handling these problems, disaster risk reduction efforts are needed by taking into account the regional developments. The purposes of this research are to identify the level of disaster risk, the level of regional development, and to find out the relationship between disaster risk and the level of regional development in Banten Province. This research was conducted using the literature study method, by searching and studying various literatures. Data analysis was performed using scoring techniques and an integrated model of the relationship between regional development and disaster risk, with the unit of analysis is district/ city. The results showed that there were 2 typologies of the relationship between disaster risk and regional development in Banten Province, 5 districts/ cities (Pandeglang Regency, Lebak Regency, Tangerang Regency, Serang Regency and Tangerang City) in typology I (high) and 3 districts/ cities (Cilegon City, Serang City, and Tangerang Selatan City) in typology III (low).
\end{abstract}

Keywords: hazard, vulnerability, capacity, disaster risk, regional development, banten province.

\begin{abstract}
Abstrak
Provinsi Banten merupakan salah satu wilayah yang rentan terhadap bencana, karena memiliki berbagai macam ancaman bencana. Disisi lain, proses perkembangan wilayah terus berjalan seiring berjalannya waktu dan segala macam aktivitas manusia yang ada di dalamnya. Guna menangani permasalahan tersebut, perlu upaya-upaya pengurangan risiko bencana dengan memperhatikan perkembangan wilayah yang ada. Tujuan dari penelitian ini adalah untuk mengidentifikasi tingkat risiko bencana, tingkat perkembangan wilayah, dan mengetahui hubungan antara risiko bencana dan tingkat perkembangan wilayah yang ada di Provinsi Banten. Penelitian ini dilakukan dengan metode studi kepustakaan, dengan mencari dan mempelajari berbagai literatur terkait. Analisis data dilakukan dengan teknik skoring dan model integrasi hubungan perkembangan wilayah dan risiko bencana, dengan unit analisis kabupaten/ kota. Hasil penelitian menunjukkan bahwa terdapat 2 tipologi hubungan antara risiko bencana dan perkembangan wilayah di Provinsi Banten, yaitu terdapat 5 kabupaten/ kota (Kabupaten Pandeglang, Kabupaten Lebak, Kabupaten Tangerang, Kabupaten Serang dan Kota Tangerang) masuk tipologi I (tinggi) dan 3 kabupaten/ kota (Kota Cilegon, Kota Serang, dan Kota Tangerang Selatan) masuk tipologi III (rendah).
\end{abstract}

Kata kunci: ancaman, kerentanan, kapasitas, risiko bencana, perkembangan wilayah, provinsi banten. 


\section{PENDAHULUAN}

\subsection{Latar Belakang}

Provinsi Banten merupakan pemekaran wilayah dari Provinsi Jawa Barat berdasarkan Undang-undang Nomor 23 Tahun 2000, tentang pembentukan Provinsi Banten yang disahkan pada tanggal 18 November 2000. Adapun tujuan pembentukan Provinsi Banten adalah untuk meningkatkan kesejahteraan masyarakat Banten yang selama berada pada wilayah administratif Provinsi Jawa Barat relatif tertinggal.

Provinsi Banten merupakan wilayah penyangga ibu kota negara, memiliki luas wilayah 9.662,92 km² yang terbagi ke dalam 4 kabupaten dan 4 kota (BPS Provinsi Banten, 2020). Menurut Wijono (2017) Provinsi Banten memiliki posisi geografis yang sangat strategis, terletak di ujung barat pulau Jawa dan berada di pintu Selat Sunda. Provinsi Banten dapat dikatakan berfungsi sebagai pintu gerbang barat dari kepulauan Nusantara dan merupakan lintas perdagangan nasional maupun internasional.

Menurut Alkadri (2011) Provinsi Banten berbatasan langsung dengan DKI Jakarta yang merupakan Ibu Kota Negara Republik Indonesia, sehingga Provinsi Banten juga berperan sebagai bagian dari sirkulasi perdagangan internasional, serta menjadi lokasi aglomerasi perekonomian dan permukiman yang potensial. Oleh karena itu, dalam Rencana Tata Ruang Wilayah Provinsi Banten 2010 - 2030 ditetapkanlah tujuan penataan ruang wilayah Provinsi Banten, yaitu mewujudkan ruang wilayah Banten sebagai pintu gerbang simpul nasionalinternasional yang aman, nyaman, produktif dan berkelanjutan melalui pengembangan pusat-pusat pertumbuhan yang mendukung ketahanan pangan, industri, dan pariwisata (Bappeda Provinsi Banten, 2010).

Disisi lain, secara geografis Provinsi Banten merupakan salah satu daerah dengan kondisi wilayah yang rentan terhadap berbagai potensi ancaman bencana alam. Selain itu, berkaitan dengan posisi strategisnya, Provinsi Banten dari waktu ke waktu terus berkembang dengan pesatnya menuju ke arah 'perkotaan'. Hal tersebut dibarengi dengan urbanisasi dan pembangunan berbagai infrastruktur perkotaan. Konversi penggunaan lahan dilakukan dengan kurang mempertimbangkan keseimbangan ekologis. Kondisi ini kemudian berujung pada semakin meningkatnya dampak kejadian bencana.

Provinsi Banten secara umum merupakan dataran rendah dengan ketinggian 0 - 257,93 meter dpl (di atas permukaan laut), serta memiliki beberapa gunung dengan ketinggian mencapai 2.000 mdpl (BPS Provinsi Banten, 2020). Berdasarkan hasil kajian yang dilakukan oleh BNPB (2015) wilayah Provinsi Banten memiliki kompleksitas ancaman, baik bencana alam maupun sosial. Jika ancaman bencana yang ada bertemu dengan kondisi sosial-budaya, ekonomi, fisik, dan lingkungan yang rentan tanpa didukung oleh kapasitas masyarakat yang baik, maka ancaman bencana tersebut dapat menjelma menjadi bencana yang memiliki dampak besar.

Menurut Soleman et al. (2012) bencana alam yang terjadi di Provinsi Banten antara lain banjir, longsor, gempabumi, abrasi dan tsunami. Berbagai macam jenis bencana tersebut memerlukan tindakan mitigasi agar jumlah korban dan kerugian akibat bencana alam dapat dikurangi. Oleh karena itu perlu direncanakan upaya terkait pengurangan risiko bencana untuk meminimalisir risiko. Salah satu upaya komprehensif yang dapat dilakukan adalah dengan melakukan perencanaan pengembangan wilayah berbasis pengurangan risiko bencana di Provinsi Banten.

\subsection{Tujuan Penelitian}

Tujuan dari penelitian ini adalah:

a. Mengidentifikasi tingkat risiko bencana di Provinsi Banten.

b. Mengidentifikasi tingkat perkembangan wilayah di Provinsi Banten.

c. Mengetahui hubungan risiko bencana dan tingkat perkembangan wilayah di Provinsi Banten.

\section{METODE PENELITIAN}

\subsection{Metode}

Penelitian ini merupakan penelitian kepustakaan (literature research), yaitu metode penelitian yang dilakukan dengan cara mencari dan mempelajari berbagai literatur, karya ilmiah dan buku-buku yang berhubungan dengan judul penelitian. Menurut Nazir (1988), studi pustaka adalah teknik pengumpulan data dengan melakukan penelaahan terhadap berbagai buku, literatur, catatan, serta berbagai laporan yang berkaitan dengan masalah yang ingin dipecahkan.

Metode analisis data dilakukan dengan teknik skoring dan model integrasi hubungan perkembangan wilayah dan risiko bencana, dengan unit analisis kabupaten/ kota. Teknik skoring/ indeks tertimbang dilakukan dengan masing-masing indikator yang memiliki satuan berbeda diberi nilai skor, sehingga memiliki satuan yang sama. Pemberian skor dilakukan 
berdasarkan sebaran data nilai terendah sampai tertinggi. Jumlah kelas nilai ditetapkan menjadi 3 (tinggi; sedang; dan rendah). Metode penentuan interval menggunakan equal interval, yaitu penentuan interval dalam kelas dengan cara menentukan jumlah interval yang sama, setelah membagi selisih nilai tertinggi dan terendah dengan jumlah kelas yang ditentukan (Muta'ali, 2014). Interval kelas ditentukan dengan cara nilai maksimal dikurangi nilai minimal, kemudian dibagi jumlah kelas (3 kelas).

Metode penentuan interval dalam klasifikasi dengan ketentuan seperti terlihat pada Tabel 1.

Tabel 1. Metode Penentuan Interval Skor dalam Klasifikasi

\begin{tabular}{l|l}
\hline \multicolumn{1}{c|}{ Kelas } & \multicolumn{1}{c}{ Interval Skor } \\
\hline Rendah (skor 1) & (Nilai minimal) s/d (Nilai minimal + interval) \\
\hline Sedang (skor 2) & (Nilai minimal + interval $+0,01)$ s/d (Nilai minimal + 2interval) \\
\hline Tinggi (skor 3) & (Nilai minimal + 2interval $+0,01)$ s/d (Nilai maksimal) \\
\hline Sumber: Muta'ali (2014)
\end{tabular}

Tingkat risiko bencana dianalisis menggunakan matriks hubungan antara ancaman $(\mathrm{H})$ - kerentanan $(\mathrm{V})$ dan matriks risiko $(R)$ sebagai berikut.

\begin{tabular}{c|c|c|c}
\hline Rendah & Sedang & Rendah & Rendah \\
\hline Sedang & Tinggi & Sedang & Rendah \\
\hline Tinggi & Tinggi & Tinggi & Sedang \\
\hline Gambar 1. & $\begin{array}{l}\text { Matriks Ancaman (H) } \\
\text { (V) Kerentanan }\end{array}$ \\
Priatmodjo, 2016) \\
Pudibyakto dan \\
\hline C & Tinggi & Sedang & Rendah \\
\hline Tinggi & Sedang & Rendah & Rendah \\
\hline Sedang & Tinggi & Sedang & Rendah \\
\hline Rendah & Tinggi & Tinggi & Sedang \\
\hline Gambar 2. & $\begin{array}{l}\text { Matriks Risiko (R) } \\
\text { (Sumber: }\end{array}$ \\
Sudibyakto dan Priatmodjo, 2016)
\end{tabular}

Model integrasi hubungan risiko bencana dan perkembangan wilayah dilakukan dengan menggunakan matriks seperti terlihat pada Gambar 3.

\begin{tabular}{c|c|c|c}
\hline \multirow{2}{*}{ Risiko } & \multicolumn{3}{|c}{ Perkembangan Wilayah } \\
\cline { 2 - 4 } Bencana & Tinggi & Sedang & Rendah \\
\hline Tinggi & Sedang & Tinggi & Tinggi \\
\hline Sedang & Rendah & Sedang & Tinggi \\
\hline Rendah & Rendah & Rendah & Sedang \\
\hline Gambar 3. & $\begin{array}{l}\text { Matriks Hubungan Risiko } \\
\text { dan Bencana }\end{array}$ & $\begin{array}{c}\text { Perkembangan } \\
\text { (Sumber: Muta'ali, 2014) }\end{array}$ & Wilayah \\
&
\end{tabular}

\subsection{Variabel dan Indikator}

Variabel dan indikator yang digunakan dalam penelitian ini meliputi dua hal, yaitu variabel dan indikator risiko bencana (Tabel 2), serta variabel dan indikator perkembangan wilayah (Tabel 3).

Tabel 2. Variabel dan Indikator Risiko Bencana

\begin{tabular}{c|lrl}
\hline \multicolumn{1}{c|}{ Variabel } & \multicolumn{2}{|c}{ Indikator } \\
\hline A. Ancaman & $\begin{array}{l}\text { 1) Jumlah dan jenis ancaman } \\
\text { bencana. }\end{array}$ & \\
\hline B. Kerentanan & 1) & Tingkat & kepadatan \\
\hline
\end{tabular}

\begin{tabular}{l|lr}
\hline Variabel & \multicolumn{2}{|c}{ Indikator } \\
\hline & penduduk; 2) Persentase \\
jumlah penduduk rentan \\
(miskin); 3) Persentase jumlah \\
penduduk rentan (0-15 tahun); \\
4) Persentase jumlah \\
pengangguran terbuka; dan 5) \\
& $\begin{array}{l}\text { Persentase jumlah bangunan } \\
\text { rumah semi permanen (dinding }\end{array}$ \\
& bukan tembok). \\
\hline C. Kapasitas & $\begin{array}{l}\text { 1) Jumlah taruna siaga } \\
\text { bencana; dan 2) Persentase }\end{array}$ \\
& jumlah bangunan rumah \\
& permanen (dinding tembok). \\
\hline
\end{tabular}

Sumber: Modifikasi dari Muta'ali (2014)

Tabel 3. Variabel dan Indikator Perkembangan Wilayah

\begin{tabular}{|c|c|}
\hline \multicolumn{2}{|l|}{ 1.Dimensi Ekonomi } \\
\hline Variabel & Indikator \\
\hline A. Pendapatan & $\begin{array}{l}\text { 1) Daya beli/ pengeluaran } \\
\text { per kapita sebulan; dan 2) } \\
\text { PDRB per kapita. }\end{array}$ \\
\hline B. Ketenagakerjaan & $\begin{array}{l}\text { 1) Pekerjaan di sektor } \\
\text { formal/ jumlah PNS } \\
\text { terhadap angkatan kerja; } \\
\text { dan 2) Jumlah penduduk } \\
\text { bekerja } \\
\text { angkatan kerja. }\end{array}$ \\
\hline $\begin{array}{l}\text { C. Kemampuan } \\
\begin{array}{l}\text { keuangan } \\
\text { daerah }\end{array} \\
\end{array}$ & $\begin{array}{l}\text { 1) Jumlah Pendapatan } \\
\text { Asli Daerah (PAD). }\end{array}$ \\
\hline \multicolumn{2}{|l|}{ 2. Dimensi Sosial } \\
\hline A. Pendidikan & $\begin{array}{l}\text { 1) Angka Melek Huruf } \\
\text { (AMH); 2) Penduduk } \\
\text { menamatkan perguruan } \\
\text { tinggi (D1-S3); dan 3) } \\
\text { Angka Partisipasi Sekolah } \\
\text { umur 7-18 tahun. }\end{array}$ \\
\hline B. Kesehatan & $\begin{array}{l}\text { 1) Angka Harapan Hidup } \\
(\mathrm{AHH}) \text {. }\end{array}$ \\
\hline C. Kependudukan & $\begin{array}{l}\text { 1) Pertumbuhan } \\
\text { penduduk; dan }\end{array}$ \\
\hline
\end{tabular}

3. Dimensi Infrastruktur Pelayanan Publik

\begin{tabular}{l|lr}
\hline A. Pendidikan & 1) Rasio murid SD/MI \\
terhadap jumlah SD/Ml; 2) \\
Rasio murid SLTP \\
terhadap jumlah SLTP; \\
dan 3) Rasio murid SLTA
\end{tabular}




\begin{tabular}{|c|c|}
\hline & terhadap jumlah SLTA. \\
\hline B. Kesehatan & $\begin{array}{lr}\text { 1) Rasio } & \text { puskesmas } \\
\text { terhadap } & \text { jumlah } \\
\text { penduduk; } & \text { dan } 2 \text { 2) } \\
\text { Persentase } & \text { tenaga } \\
\text { kesehatan. } & \\
\end{array}$ \\
\hline C. Keuangan & $\begin{array}{l}\text { 1) Rasio kantor bank per } \\
\text { kecamatan. }\end{array}$ \\
\hline \multicolumn{2}{|c|}{ 4. Dimensi Teknologi dan Komunikasi } \\
\hline A. Teknologi & $\begin{array}{ll}\text { 1) Rumah } & \text { tangga } \\
\text { menguasai } & \text { komputer/ } \\
\text { laptop; dan } & \text { 2) Rumah } \\
\text { tangga } & \text { mengakses } \\
\text { internet. } & \\
\end{array}$ \\
\hline B. Komunikasi & $\begin{array}{l}\text { 1) Rasio kantor pos/ } \\
\text { kecamatan; dan 2) Rumah } \\
\text { tangga menguasai HP. }\end{array}$ \\
\hline
\end{tabular}

Sumber: Modifikasi dari BPS (2011)

\section{HASIL DAN PEMBAHASAN}

\subsection{Deskripsi Wilayah Penelitian}

\subsubsection{Kondisi Geografis}

Provinsi Banten dibentuk berdasarkan Undang-Undang Nomor 23 Tahun 2000, yang pada awal berdirinya terdiri atas 4 Kabupaten (Serang, Pandeglang, Lebak, dan Tangerang) dan 2 kota (Tangerang dan
Cilegon). Namun dalam perkembangannya terjadi pemekaran wilayah, dimana Kabupaten Serang menjadi Kabupaten Serang dan Kota Serang, sedangkan Kabupaten Tangerang dimekarkan juga menjadi Kabupaten Tangerang dan Kota Tangerang Selatan. Dengan demikian Provinsi Banten saat ini terdiri dari empat kabupaten dan empat kota.

Menurut (BPS Provinsi Banten, 2020) wilayah Provinsi Banten berada pada batas

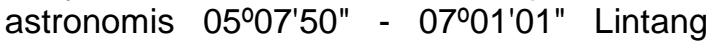
Selatan dan 10501'11" - 10607'12" Bujur Timur. Batas-batas wilayah Provinsi Banten adalah sebagai berikut:

- Sebelah utara berbatasan dengan Laut Jawa.

- Sebelah timur berbatasan dengan Provinsi DKI Jakarta dan Jawa Barat.

- Sebelah selatan berbatasan dengan Samudra Hindia.

- Sebelah barat berbatasan dengan Selat Sunda.

Adapun pembagian wilayah secara administrasi di Propinsi Banten dapat dilihat pada Gambar 4.

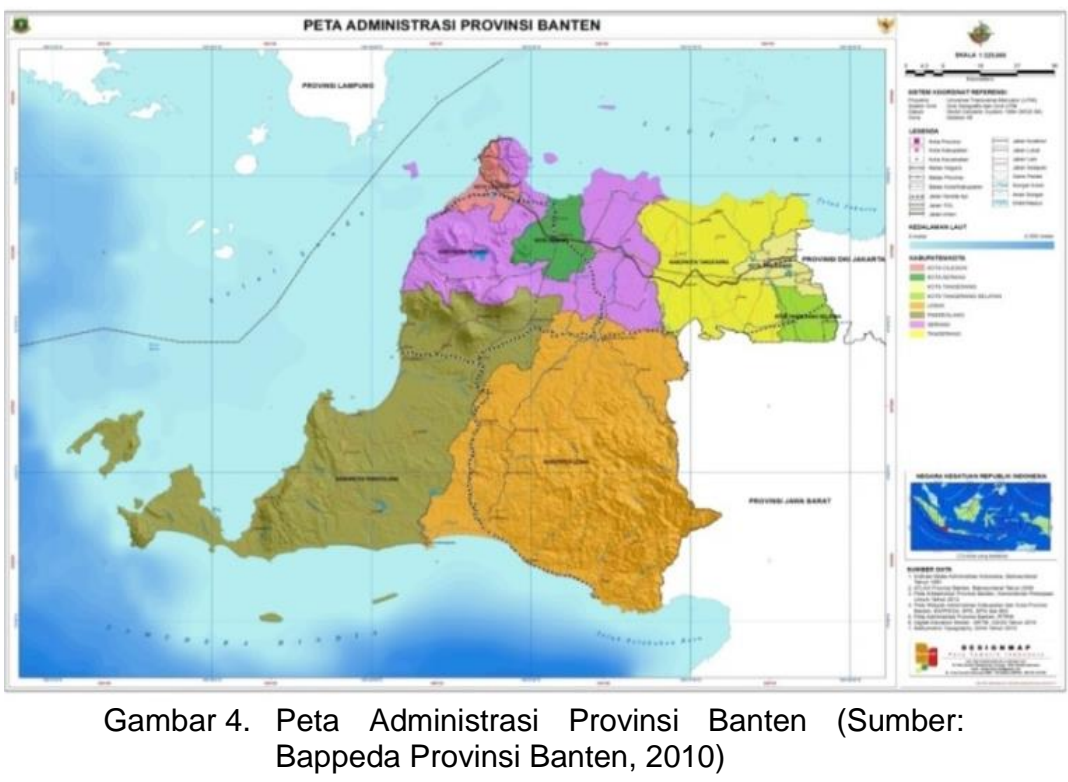

\subsubsection{Kondisi Topografi}

Menurut Bappeda Provinsi Banten (2010), topografi wilayah Provinsi Banten berkisar pada ketinggian $0-1.000 \mathrm{mdpl}$. Secara umum kondisi topografi wilayah Provinsi Banten merupakan dataran rendah yang berkisar antara $0-200 \mathrm{mdpl}$ yang terletak di daerah Kota Cilegon, Kota Tangerang, Kabupaten Pandeglang, dan sebagian besar Kabupaten Serang. Adapun daerah Lebak Tengah dan sebagian kecil Kabupaten Pandeglang memiliki ketinggian berkisar 201 - 2.000 mdpl dan daerah Lebak
Timur memiliki ketinggian $501-2.000$ mdpl yang terdapat di Puncak Gunung Sanggabuana dan Gunung Halimun.

Kondisi topografi suatu wilayah berkaitan dengan bentuk permukaan wilayah atau morfologi. Menurut Bappeda Provinsi Banten (2010) morfologi wilayah Provinsi Banten secara umum terbagi menjadi tiga kelompok, yaitu morfologi dataran, perbukitan landai-sedang (bergelombang rendahsedang) dan perbukitan terjal. Morfologi dataran rendah umumnya terdapat di daerah bagian utara dan sebagian selatan. Wilayah 
dataran merupakan wilayah yang mempunyai ketinggian kurang dari $50 \mathrm{mdpl}$ sampai wilayah pantai yang mempunyai ketinggian 01 mdpl. Morfologi Perbukitan bergelombang rendah - sedang sebagian besar menempati daerah bagian tengah. Wilayah perbukitan terletak pada wilayah yang mempunyai ketinggian minimum 50 mdpl.

\subsubsection{Kondisi Geologi}

Menurut BLHD Provinsi Banten (2015) secara umum kondisi geologi Provinsi Banten lebih banyak dicirikan oleh formasi batuan vulkanik. Formasi batuan vulkanik tersebut berumur lebih muda dibandingkan dengan batuan sedimen yang mendasarinya. Beberapa wujud aktivitas vulkanik di masa lalu ditunjukkan oleh adanya gunungapigunungapi yang menjulang di wilayah ini, seperti Gunungapi Karang, Aseupan, Pulosari, Gede, dan banyak lagi gunungapi yang lebih kecil, namun pada saat ini kesemuanya dalam fase dormant.

Menurut Bappeda Provinsi Banten (2010) batuan Gunungapi dapat dikelompokan dalam batuan gunungapi tua dan muda yang berumur plistosen tua hingga holosen. Batuan terobosan yang dijumpai bersusunan andesiot sampai basal. Tuf Cikasungka berumur plistosen, Lava Halimun dan batuan gunungapi Kuarter. Pada peta lembar Leuwidamar disajikan pula singkapan batuan metamorf yang diduga berumur Ologo Miosen terdiri dari Sekis, Genes dan Amfibolit yang tersingkap di bagian utara tubuh Granodiorit Cihara.

Struktur geologi daerah Banten terdiri dari formasi batuan dengan tingkat ketebalan dari tiap-tiap formasi berkisar antara 200 $800 \mathrm{~m}$ dan tebal keseluruhan diperkirakan melebihi $3.500 \mathrm{~m}$. Formasi Bojongmanik merupakan satuan tertua berusia Miosen akhir, batuannya terdiri dari perselingan antara batu pasir dan lempung pasiran, batu gamping, batu pasir tufaan, konglomerat dan breksi andesit, umurnya diduga Pliosen awal. Berikutnya adalah Formasi Cipacar yang terdiri dari tuf batu apung berselingan dengan lempung tufaan, konglomerat dan napal glaukonitan, umurnya diiperkirakan Pliosen akhir. Di atas formasi ini adalah Formasi Bojong yang terdiri dari napal pasiran, lempung pasiran, batu gamping kokina dan tuf (Bappeda Provinsi Banten, 2010).

\subsubsection{Jenis Tanah}

Sumber daya tanah wilayah Provinsi Banten secara geografis terbagi dua tipe tanah yaitu: (a) kelompok tipe tanah sisa atau residu dan (b) kelompok tipe tanah hasil angkutan. Secara umum distribusi dari masing-masing tipe tanah ini di wilayah Provinsi Banten, terdapat di Kabupaten Serang, Kabupaten Lebak, Kabupaten Pandeglang, Kabupaten Tangerang, Kota Tangerang dan Kota Cilegon. Masing-masing tipe tanah yang terdapat di wilayah tersebut antara lain: 1. Aluvial pantai dan sungai; 2 . Latosol; 3. Podsolik merah kuning; 4. Regosol; 5. Andosol; 6. Brown forest; dan 7. Glei (BLHD Provinsi Banten, 2015).

\subsubsection{Kondisi Hidrologi}

Menurut BLHD Provinsi Banten (2015) berdasarkan karakteristik iklim dan geomorfologi yang ada, Provinsi Banten tergolong mempunyai potensi sumberdaya air tanah yang banyak. Hal ini disebabkan oleh curah hujan yang terjadi di Provinsi Banten relatif tinggi, sedangkan bentuk lahan didominasi oleh bentuk lahan vulkanik. Produk vulkanik, seperti piroklastik yang terdiri atas abu, pasir, dan kerikil, adalah material-material permukaan yang sifatnya cukup porus, sehingga material ini dengan mudah akan dapat meloloskan air untuk masuk ke dalam tanah. Namun demikian potensi tersebut juga tergantung kepada bagaimana kondisi tutupan lahan di atasnya, terutama di wilayah-wilayah perbukitan dan pegunungan (uplands). Tutupan lahan vegetasi merupakan tutupan terbaik untuk membantu mengurangi terjadinya aliran permukaan (overland flow) dan sebaliknya dapat meningkatkan laju perkolasi air ke dalam tanah.

Menurut Bappeda Provinsi Banten (2010) potensi sumber daya air wilayah Provinsi Banten banyak ditemui di Kabupaten Lebak, sebab sebagian besar wilayahnya merupakan kawasan hutan lindung dan hutan produksi terbatas. Berdasarkan pembagian Daerah Aliran Sungai (DAS), Provinsi Banten dibagi menjadi enam DAS, yaitu:

- DAS Ujung Kulon, meliputi wilayah bagian Barat Kabupaten Pandeglang (Taman Nasional Ujung Kulon dan sekitarnya);

- DAS Cibaliung-Cibareno, meliputi bagian Selatan wilayah Kabupaten Pandeglang dan bagian selatan wilayah Kabupaten Lebak;

- DAS Ciujung-Cidurian, meliputi bagian Barat wilayah Kabupaten Pandeglang;

- DAS Rawadano, meliputi sebagian besar wilayah Kabupaten Serang dan Kabupaten Pandeglang;

- DAS Teluklada, meliputi bagian Selatan wilayah Kabupaten Lebak dan Kabupaten Pandeglang; dan

- DAS Cisadane-Ciliwung, meliputi bagian Timur wilayah Kabupaten Tangerang dan Kota Tangerang. 


\subsubsection{Kondisi Iklim}

Iklim wilayah Banten sangat dipengaruhi oleh Angin Monson (Monson Trade) dan Gelombang La Nina atau El Nino. Saat musim penghujan (November - Maret) cuaca didominasi oleh angin Barat (dari Sumatera, Samudra Hindia sebelah selatan India) yang bergabung dengan angin dari Asia yang melewati Laut Cina Selatan. Pada bulan Agustus cuaca didominasi oleh angin Timur yang menyebabkan wilayah Banten mengalami kekeringan yang keras terutama di wilayah bagian pantai utara, terlebih lagi bila berlangsung EI Nino. Temperatur di daerah pantai dan perbukitan berkisar antara $22^{\circ} \mathrm{C}$ dan $32^{\circ} \mathrm{C}$, sedangkan suhu di pegunungan dengan ketinggian antara 400 $1.350 \mathrm{~m}$ dpl mencapai antara $18^{\circ} \mathrm{C}-29^{\circ} \mathrm{C}$ (Bappeda Provinsi Banten 2010).

Persebaran jumlah curah hujan cukup bervariasi tergantung pada lalitude, posisi geografis, dan kondisi topografis. Salah satu klasifikasi iklim yang banyak dipakai di Indonesia adalah klasifikasi Oldeman, karena terkait dengan bidang pertanian. Dimana klasifikasi Oldeman mempertimbangkan jumlah curah hujan yang dipilah menjadi 3 , yaitu bulan basah ( $>200 \mathrm{~mm}$ ), bulan lembab $(100-200 \mathrm{~mm})$, dan bulan kering $(<100 \mathrm{~mm})$. Berdasarkan klasifikasi Oldeman sebagian besar Provinsi Banten tergolong mempunyai bulan basah yang tinggi (terutama di selatan dan tengah), sedangkan di bagian utara memiliki bulan-bulan basah yang rendah. Berdasarkan hal tersebut sumberdaya air Provinsi Banten tergolong sangat baik (BLHD Provinsi Banten, 2015).

\subsection{Kebijakan Pengurangan Risiko Bencana Provinsi Banten}

Berdasarkan visi pembangunan Provinsi Banten tahun 2005 - 2025 (Banten Mandiri, Maju, Sejahtera Berlandaskan Iman dan Taqwa), selanjutnya ditetapkan misi pembangunan Provinsi Banten tahun 2005 2025 sebagai bentuk konkret upaya mewujudkan visi pembangunan tersebut. Salah satu misi yang ditetapkan terkait dengan pengurangan risiko bencana, yaitu misi ke-3, yang berbunyi "Mewujudkan Pengelolaan Sumber Daya Alam dan Lingkungan Hidup yang Lestari".

Adapun tujuan dan sasaran yang ditetapkan terkait dengan misi ke-3 pembangunan jangka panjang Provinsi Banten, yang merupakan suatu bentuk komitmen yang menjadi pedoman dan acuan bagi seluruh pemangku kepentingan dalam menyelaraskan derap langkah mewujudkan visi pembangunan 2005 - 2025 dapat dilihat pada Tabel 4 .

Tabel 4. Tujuan dan Sasaran Misi ke-3 dalam Rencana Pembangunan Jangka Panjang Provinsi Banten Tahun

\begin{tabular}{|c|c|}
\hline $\begin{array}{r}\text { Tujuan } \\
\end{array}$ & Sasaran \\
\hline 1. Meningkatkan kualitas penataan ruang. & $\begin{array}{l}\text { 1.1. Meningkatnya } \\
\begin{array}{l}\text { Memanfaatan, dan pengendalian tata ruang } \\
\text { daerah. }\end{array}\end{array}$ \\
\hline $\begin{array}{l}\text { 2. Meningkatkan pengelolaan dan pelestarian } \\
\text { sumberdaya alam. }\end{array}$ & $\begin{array}{l}\text { 2.1. Meningkatnya kualitas pengelolaan dan } \\
\text { pelestarian sumber daya alam. }\end{array}$ \\
\hline 3. Meningkatkan kualitas lingkungan hidup. & $\begin{array}{l}\text { 3.1. Terjaganya daya dukung lingkungan hidup. } \\
\text { 3.2. Menurunnya tingkat pencemaran dan perusakan } \\
\text { lingkungan hidup. }\end{array}$ \\
\hline 4. Mitigasi dampak bencana. & $\begin{array}{l}\text { 4.1. Berkurangnya korban jiwa, kerugian moril, dan } \\
\text { kerugian materil akibat bencana alam, bencana } \\
\text { lingkungan, dan bencana industri. }\end{array}$ \\
\hline
\end{tabular}

Sumber: Bappeda Provinsi Banten (2005)

Provinsi Banten sudah memiliki Badan Penanggulangan Bencana Daerah (BPBD) berdasarkan Peraturan Daerah Provinsi Banten Nomor 3 Tahun 2010. Visi dari BPBD Provinsi Banten adalah "Profesional dan Kearifan Lokal dalam Penanggulangan Bencana". Guna mewujudkan visi tersebut ditetapkan misi antara lain:

a. Melindungi masyarakat Banten dengan mengutamakan pengurangan risiko bencana.

b. Membangun sistem penanggulangan bencana yang efektif, efisien dan handal. c. Menyelenggarakan penanggulangan
bencana secara profesional dan terkoordinasi.

Selain itu, semua kabupaten/kota yang berada di wilayah Provinsi Banten juga sudah memiliki BPBD masing-masing, sehingga sudah ada yang menjadi komando dalam hal penanganan masalah bencana di setiap wilayah yang ada di Provinsi Banten.

\subsection{Risiko Bencana di Provinsi Banten}

Pengkajian risiko merupakan dasar perhitungan pengkajian setiap ancaman yang memiliki potensi untuk menjadi bencana. 
Perhitungan tersebut didasarkan pada parameter-parameter dasar sebagai alat ukur standar dalam penentuan masing-masing komponen yang berpengaruh terhadap potensi bencana. Komponen tersebut antara lain ancaman, kerentanan, dan kapasitas.

\subsubsection{Ancaman Bencana di Provinsi Banten}

Pengkajian indeks ancaman bencana dilakukan untuk seluruh jenis bencana yang berpotensi terjadi di Provinsi Banten. Berdasarkan data Kajian Risiko Bencana Provinsi Banten 2016 - 2020 yang penyusunannya difasilitasi oleh BNPB, diperoleh data mengenai jumlah ancaman bencana disetiap kabupaten/ kota yang ada di Provinsi Banten sebagai berikut:

Tabel 5. Ancaman Bencana di Provinsi Banten Tahun 2016 - 2020

\begin{tabular}{|c|c|c|c|c|c|c|c|c|c|c|c|c|}
\hline \multirow{2}{*}{ Kab/ Kota } & \multicolumn{11}{|c|}{ Jenis Ancaman Bencana } & \multirow{2}{*}{ Jumlah } \\
\hline & (1) & (2) & (3) & (4) & (5) & (6) & (7) & (8) & (9) & $(10)$ & (11) & \\
\hline Kab. Pandeglang & $\sqrt{ }$ & $\sqrt{ }$ & $\sqrt{ }$ & $\sqrt{1}$ & $\sqrt{ }$ & $\sqrt{ }$ & $\sqrt{ }$ & $\sqrt{ }$ & $\sqrt{ }$ & - & $\sqrt{1}$ & 10 \\
\hline Kab. Lebak & $\sqrt{ }$ & $\sqrt{ }$ & $\sqrt{ }$ & $\sqrt{ }$ & $\sqrt{ }$ & $\sqrt{ }$ & $\sqrt{ }$ & $\sqrt{ }$ & $\sqrt{ }$ & - & $\sqrt{ }$ & 10 \\
\hline Kab. Tangerang & $\sqrt{ }$ & $\sqrt{ }$ & $\sqrt{ }$ & - & $\sqrt{ }$ & $\sqrt{ }$ & $\sqrt{ }$ & $\sqrt{ }$ & $\sqrt{ }$ & $\sqrt{ }$ & $\sqrt{ }$ & 10 \\
\hline Kab. Serang & $\sqrt{ }$ & $\sqrt{ }$ & $\sqrt{ }$ & $\sqrt{ }$ & $\sqrt{ }$ & $\sqrt{ }$ & $\sqrt{ }$ & $\sqrt{ }$ & $\sqrt{ }$ & $\sqrt{ }$ & $\sqrt{ }$ & 11 \\
\hline Kota Tangerang & $\sqrt{ }$ & $\sqrt{ }$ & $\sqrt{ }$ & $\sqrt{ }$ & - & $\sqrt{ }$ & - & $\sqrt{ }$ & $\sqrt{ }$ & $\sqrt{ }$ & - & 8 \\
\hline Kota Cilegon & $\sqrt{ }$ & $\sqrt{ }$ & $\sqrt{ }$ & $\sqrt{ }$ & $\sqrt{ }$ & $\sqrt{ }$ & $\sqrt{ }$ & - & $\sqrt{ }$ & $\sqrt{ }$ & $\sqrt{ }$ & 10 \\
\hline Kota Serang & $\sqrt{ }$ & $\sqrt{ }$ & $\sqrt{ }$ & - & $\sqrt{ }$ & $\sqrt{ }$ & $\sqrt{ }$ & - & $\sqrt{ }$ & $\sqrt{ }$ & $\sqrt{ }$ & 9 \\
\hline Kota Tangsel & $\sqrt{ }$ & $\sqrt{ }$ & $\sqrt{ }$ & - & - & $\sqrt{ }$ & - & $\sqrt{ }$ & $\sqrt{ }$ & $\sqrt{ }$ & - & 7 \\
\hline
\end{tabular}

Sumber: BNPB (2015)

Keterangan: $\quad$ (1) Banjir; (2) Kekeringan; (3) Cuaca ekstim; (4) Tanah longsor; (5) Gelombang ekstrim dan abrasi; (6) Gempabumi; (7) Kebakaran hutan dan lahan; (8) Banjir bandang; (9) Epidemi dan wabah penyakit; (10) Kegagalan teknologi; dan (11) Tsunami.

Berdasarkan data ancaman bencana pada Tabel 5, maka selanjutnya dapat dihitung indeks ancaman bencana yang ada di Provinsi Banten beserta klasifikasinya sebagai berikut.

Tabel 6. Indeks dan Klasifikasi Ancaman Bencana di Provinsi Banten

\begin{tabular}{l|c|c|c}
\hline $\begin{array}{c}\text { Kabupaten/ } \\
\text { Kota }\end{array}$ & $\begin{array}{c}\text { Indikator } \\
\text { (Data } \\
\text { Dasar) }\end{array}$ & $\begin{array}{c}\text { Hasil } \\
\text { Skoring }\end{array}$ & Klasifikasi \\
\hline Kab. Pandeglang & 10 & 3 & Tinggi \\
\hline Kab. Lebak & 10 & 3 & Tinggi \\
\hline Kab. Tangerang & 10 & 3 & Tinggi \\
\hline Kab. Serang & 11 & 3 & Tinggi \\
\hline Kota Tangerang & 8 & 3 & Tinggi \\
\hline Kota Cilegon & 10 & 3 & Tinggi \\
\hline Kota Serang & 9 & 3 & Tinggi \\
\hline Kota Tangsel & 7 & 2 & Sedang \\
\hline Keterangan:Data dasar merupakan jumlah \\
ancaman bencana
\end{tabular}

Berdasarkan data pada Tabel 6 maka dapat dilihat bahwa terdapat 7 kabupaten/kota yang memiliki tingkat ancaman bencana tinggi (Kabupaten Pandeglang, Kabupaten Lebak, Kabupaten Tangerang, Kabupaten Serang, Kota Tangerang, Kota Cilegon, dan Kota Serang). Hanya terdapat satu kota yang memiliki tingkat ancaman bencana sedang di Provinsi Banten, yaitu Kota Tangerang Selatan.

\subsubsection{Kerentanan di Provinsi Banten}

Menurut Muta'ali (2014) kerentanan adalah kondisi sistem di masyarakat atau wilayah yang menyebabkan ketidakmampuan dalam menghadapi bencana, baik dalam meredam, mencapai kesiapan dan menanggapi dampak bencana. Kerentanan menyangkut kerentanan fisik, sosial, ekonomi, dan lingkungan. Dalam penelitian ini variabel kerentanan yang digunakan adalah sebanyak 5 variabel, yaitu 1) persentase bangunan rumah semipermanen/dinding bukan tembok (\%); 2) tingkat kepadatan penduduk (jiwa/ha); 3) persentase penduduk rentan/nonproduktif (\%); 4) persentase penduduk rentan/ miskin (\%); dan 5) persentase pengangguran terbuka (\%).

\section{a. Kerentanan Fisik}

Kerentanan fisik dalam penelitian ini diwakili oleh variabel persentase bangunan rumah semipermanen/dinding bukan tembok (\%), dengan asumsi semakin besar persentase bangunan rumah semipermanen maka akan semakin rentan wilayah tersebut ketika terjadi bencana. Berdasarkan data dari BPS diperoleh data persentase bangunan rumah semipermanen/dinding bukan tembok (\%) di Provinsi Banten sebagai berikut.

Tabel 7. Persentase Bangunan Rumah Semipermanen/ Dinding Bukan Tembok di Provinsi Banten Tahun 2019

\begin{tabular}{l|c}
\hline Kabupaten/ Kota & $\begin{array}{c}\text { Rumah Semipermanen } \\
(\%)\end{array}$ \\
\hline Kab. Pandeglang & 37,10 \\
\hline Kab. Lebak & 36,72 \\
\hline Kab. Tangerang & 8,34 \\
\hline Kab. Serang & 9,62 \\
\hline
\end{tabular}




\begin{tabular}{|c|c|}
\hline Kota Tangerang & 1,37 \\
\hline Kota Cilegon & 2,45 \\
\hline Kota Serang & 3,39 \\
\hline Kota Tangsel & 2,65 \\
\hline
\end{tabular}

Berdasarkan data pada Tabel 7 terlihat bahwa persentase bangunan rumah semipermanen terbesar terdapat di Kabupaten Pandeglang (37,10\%), dan persentase terkecil adalah di Kota Tangerang $(1,37 \%)$. Oleh karena itu, dapat dikatakan bahwa berdasarkan variabel persentase bangunan rumah semi permanen, Kabupaten Pandeglang merupakan wilayah paling rentan jika terjadi bencana.

\section{b. Kerentanan Sosial}

Kerentanan sosial dalam penelitian ini diwakili oleh 2 variabel, yaitu tingkat kepadatan penduduk (jiwa/ha) dan persentase penduduk rentan/nonproduktif (\%). Kepadatan penduduk adalah perbandingan antara jumlah penduduk dengan luas wilayah yang dihuni. Kepadatan penduduk merupakan indikator dari tekanan penduduk di suatu daerah. Kepadatan penduduk yang tidak terkendali mengakibatkan dampak buruk terhadap lingkungan, seperti semakin terbatasnya sumber daya pokok, tidak tercukupinya fasilitas sosial dan kesehatan, dan tidak tercukupinya lapangan pekerjaan bagi tenaga kerja yang ada. Begitu juga jika dikaitkan dengan bencana, maka semakin tinggi tingkat kepadatan penduduk disuatu wilayah, akan semakin rentan jika terjadi bencana di wilayah tersebut.

Penduduk rentan jika terjadi bencana dapat digambarkan melalui penduduk usia nonproduktif menurut BPS, yaitu anak-anak usia 0 - 14 tahun dan lanjut usia 60 tahun ke atas. Terkait dengan kerentanan asumsinya adalah semakin besar persentase penduduk rentan/ nonproduktif, maka semakin rentan wilayah tersebut jika terjadi bencana. Berdasarkan data dari BPS Provinsi Banten dapat diperoleh data terkait tingkat kepadatan penduduk (jiwa/ha) dan persentase penduduk rentan/ nonproduktif (\%) di Provinsi Banten sebagai berikut.

Tabel 8. Kepadatan Penduduk dan Jumlah Penduduk Rentan di Provinsi Banten Tahun 2019

\begin{tabular}{l|c|c}
\hline Kabupaten/ Kota & $\begin{array}{c}\text { Kepadatan } \\
\text { Penduduk } \\
\text { (jiwa/km²) }\end{array}$ & $\begin{array}{c}\text { Penduduk } \\
\text { Nonproduktif } \\
(\%)\end{array}$ \\
\hline Kab. Pandeglang & 441 & 36,53 \\
\hline Kab. Lebak & 380 & 35,26 \\
\hline Kab. Tangerang & 3.756 & 31,03 \\
\hline Kab. Serang & 870 & 33,70 \\
\hline Kota Tangerang & 14.486 & 27,45 \\
\hline
\end{tabular}

\begin{tabular}{|c|c|c|}
\hline Kota Cilegon & 2.491 & 29,99 \\
\hline Kota Serang & 2.582 & 32,97 \\
\hline Kota Tangsel & 11.875 & 27,87 \\
\hline
\end{tabular}

Berdasarkan data pada Tabel 8 terlihat bahwa kepadatan penduduk terbesar terdapat di Kota Tangerang (14.486 jiwa/km²) dan persentase penduduk rentan terbesar terdapat di Kabupaten Pandeglang (36,53\%). Oleh karena itu, dapat dikatakan bahwa berdasarkan variabel tingkat kepadatan penduduk, Kota Tangerang merupakan wilayah paling rentan jika terjadi bencana, sedangkan jika berdasarkan variabel persentase penduduk rentan, Kabupaten Pandeglang merupakan wilayah paling rentan jika terjadi bencana.

\section{c. Kerentanan Ekonomi}

Kerentanan ekonomi dalam penelitian ini diwakili oleh 2 variabel, yaitu persentase penduduk rentan/ miskin (\%) dan persentase pengangguran terbuka (\%). Terkait dengan kerentanan asumsinya adalah semakin besar persentase penduduk rentan/ miskin dan persentase pengangguran terbuka, maka semakin rentan wilayah tersebut jika terjadi bencana. Berdasarkan data BPS Provinsi Banten diperoleh data persentase penduduk rentan/ miskin dan persentase pengangguran terbuka di Provinsi Banten sebagai berikut.

Tabel 9. Penduduk Miskin dan Pengangguran Terbuka di Provinsi Banten Tahun 2019

\begin{tabular}{l|c|c}
\hline Kabupaten/ Kota & $\begin{array}{c}\text { Penduduk } \\
\text { Miskin (\%) }\end{array}$ & $\begin{array}{c}\text { Pengangguran } \\
\text { Terbuka (\%) }\end{array}$ \\
\hline Kab. Pandeglang & 9,42 & 8,71 \\
\hline Kab. Lebak & 8,30 & 8,05 \\
\hline Kab. Tangerang & 5,14 & 8,91 \\
\hline Kab. Serang & 4,08 & 10,65 \\
\hline Kota Tangerang & 4,43 & 7,13 \\
\hline Kota Cilegon & 3,03 & 9,68 \\
\hline Kota Serang & 5,28 & 8,08 \\
\hline Kota Tangsel & 1,68 & 4,79 \\
\hline
\end{tabular}

Sumber: BPS Provinsi Banten (2020)

Berdasarkan data pada Tabel 9 terlihat bahwa persentase penduduk miskin terbesar adalah Kabupaten Pandeglang (9,42\%), sehingga berdasarkan variabel tersebut Kabupaten Pandeglang merupakan wilayah paling rentan jika terjadi bencana. Persentase pengangguran terbuka terbesar adalah Kabupaten Serang (10,65\%), sehingga berdasarkan variabel tersebut Kabupaten Serang merupakan wilayah paling rentan jika terjadi bencana.

Berdasarkan data dari kerentanan fisik, sosial, dan ekonomi, maka selanjutnya dapat dihitung indeks kerentanan yang ada di Provinsi Banten beserta klasifikasinya sebagai berikut. 
Tabel 10. Indeks dan Klasifikasi Kerentanan di Provinsi Banten

\begin{tabular}{|c|c|c|c|c|c|c|c|c|c|c|c|c|}
\hline \multirow{3}{*}{ Kabupaten/ Kota } & \multicolumn{12}{|c|}{ Kerentanan } \\
\hline & \multicolumn{5}{|c|}{ Indikator (Data Dasar) } & \multicolumn{5}{|c|}{ Hasil Skoring } & \multirow{2}{*}{\begin{tabular}{|c|} 
Total Skor \\
$(1+2+3+4+5)$
\end{tabular}} & \multirow{2}{*}{ Klasifikasi } \\
\hline & $(1)$ & (2) & (3) & (4) & (5) & (1) & (2) & (3) & (4) & (5) & & \\
\hline Kab. Pandeglang & 37,10 & 441 & 36,53 & 9,42 & 8,71 & 3 & 1 & 3 & 3 & 3 & 13 & Tinggi \\
\hline Kab. Lebak & 36,72 & 380 & 35,26 & 8,30 & 8,05 & 3 & 1 & 3 & 3 & 2 & 12 & Tinggi \\
\hline Kab. Tangerang & 8,34 & 3.756 & 31,03 & 5,14 & 8,91 & 1 & 1 & 2 & 2 & 3 & 9 & Sedang \\
\hline Kab. Serang & 9,62 & 870 & 33,70 & 4,08 & 10,65 & 1 & 1 & 3 & 1 & 3 & 9 & Sedang \\
\hline Kota Tangerang & 1,37 & 14.486 & 27,45 & 4,43 & 7,13 & 1 & 3 & 1 & 2 & 2 & 9 & Sedang \\
\hline Kota Cilegon & 2,45 & 2.491 & 29,99 & 3,03 & 9,68 & 1 & 1 & 1 & 1 & 3 & 7 & Rendah \\
\hline Kota Serang & 3,39 & 2.582 & 32,97 & 5,28 & 8,08 & 1 & 1 & 2 & 2 & 2 & 8 & Rendah \\
\hline Kota Tangsel & 2,65 & 11.875 & 27,87 & 1,68 & 4,79 & 1 & 3 & 1 & 1 & 1 & 7 & Rendah \\
\hline
\end{tabular}

Keterangan: (1) persentase bangunan rumah semipermanen/dinding bukan tembok; (2) tingkat kepadatan penduduk; (3) persentase penduduk rentan/ nonproduktif; (4) persentase penduduk rentan/miskin; dan (5) persentase pengangguran terbuka.

Berdasarkan data kerentanan pada Tabel 10 maka dapat dilihat bahwa terdapat 2 kabupaten yang memiliki tingkat kerentanan tinggi, yaitu Kabupaten Pandeglang dan Lebak. Selain itu terdapat 3 kabupaten/kota yang memiliki tingkat kerentanan sedang, yaitu Kabupaten Tangerang, Kabupaten Serang, dan Kota Tangerang. Sisanya terdapat 3 kota dengan tingkat kerentanan rendah, yaitu Kota Cilegon, Kota Serang, dan Kota Tangerang Selatan.

\subsubsection{Kapasitas di Provinsi Banten}

Menurut Muta'ali (2014) kapasitas adalah suatu gabungan semua sumber daya, cara, kekuatan yang tersedia di masyarakat dan organisasi yang memungkinkan masyarakat memiliki daya tangkal dan daya tahan untuk mengurangi tingkat risiko atau akibat dari bencana. Variabel yang digunakan dalam penelitian ini untuk menggambarkan kapasitas di Provinsi Banten ada 2 variabel, yaitu persentase jumlah taruna siaga bencana dan persentase bangunan rumah permanen/dinding tembok.

Menurut Peraturan Menteri Sosial RI Nomor 128 Tahun 2011 tentang Kampung Siaga Bencana, Taruna Siaga Bencana (Tagana) adalah relawan yang berasal dari masyarakat yang memiliki kepedulian dan aktif dalam penanggulangan bencana bidang perlindungan sosial. Pembentukan Tagana merupakan suatu upaya untuk memberdayakan dan mendayagunakan generasi muda dalam berbagai aspek penanggulangan bencana, khususnya yang berbasis masyarakat. Terkait dengan bencana, asumsinya adalah semakin tinggi persentase jumlah taruna siaga bencana, maka semakin besar kapasitas wilayah tersebut jika terjadi bencana.

Bangunan rumah permanen dapat diindikasikan salah satunya adalah dari dinding rumah yang terbuat dari tembok.
Terkait dengan bencana, asumsinya adalah semakin besar persentase bangunan rumah permanen, maka semakin besar kapasitas wilayah tersebut jika terjadi bencana. Berdasarkan data dari BPS Provinsi Banten diperoleh data persentase jumlah Tagana terhadap jumlah penduduk (\%) dan persentase bangunan rumah permanen/ dinding tembok (\%) di Provinsi Banten sebagai berikut.

Tabel 11. Jumlah Tagana dan Bangunan Rumah Permanen di Provinsi Banten Tahun 2019

\begin{tabular}{l|c|c}
\hline Kabupaten/ Kota & Tagana (\%) & $\begin{array}{c}\text { Bangunan } \\
\text { Rumah } \\
\text { Permanen (\%) }\end{array}$ \\
\hline Kab. Pandeglang & 0,02 & 62,90 \\
\hline Kab. Lebak & 0,02 & 63,28 \\
\hline Kab. Tangerang & 0,01 & 91,66 \\
\hline Kab. Serang & 0,01 & 90,38 \\
\hline Kota Tangerang & 0,01 & 98,63 \\
\hline Kota Cilegon & 0,05 & 97,55 \\
\hline Kota Serang & 0,03 & 96,61 \\
\hline Kota Tangsel & 0,01 & 97,35 \\
\hline
\end{tabular}

Sumber: BPS Provinsi Banten (2020)

Berdasarkan data pada Tabel 11 terlihat bahwa persentase jumlah Tagana terbanyak adalah di Kota Cilegon (0,05\%), sehingga berdasarkan variabel tersebut Kota Cilegon merupakan wilayah yang punya kapasitas terbaik dibandingkan wilayah lainnya jika terjadi bencana. Persentase bangunan rumah permanen terbanyak adalah Kota Tangerang $(98,63 \%)$, sehingga berdasarkan variabel tersebut Kota Tangerang merupakan wilayah yang punya kapasitas terbaik jika terjadi bencana.

Berdasarkan data kapasitas pada Tabel 11, maka selanjutnya dapat dihitung indeks kapasitas yang ada di Provinsi Banten beserta klasifikasinya sebagai berikut. 
Tabel 12. Indeks dan Klasifikasi Kapasitas di Provinsi Banten

\begin{tabular}{l|c|c|c|c|c|c}
\hline \multirow{2}{*}{ Kabupaten/ Kota } & \multicolumn{2}{|c|}{$\begin{array}{c}\text { Indikator } \\
\text { Dasar) }\end{array}$} & \multicolumn{2}{c|}{ Hasil Skoring } & \multirow{2}{*}{ Total Skor } & \multirow{2}{*}{ Klasifikasi } \\
\cline { 2 - 6 } & $(1)$ & $(2)$ & $(1)$ & $(2)$ & $(1+2)$ & \\
\hline Kab. Pandeglang & 0,02 & 62,90 & 1 & 1 & 2 & Rendah \\
\hline Kab. Lebak & 0,02 & 63,28 & 1 & 1 & 2 & Rendah \\
\hline Kab. Tangerang & 0,01 & 91,66 & 1 & 3 & 4 & Sedang \\
\hline Kab. Serang & 0,01 & 90,38 & 1 & 3 & 4 & Sedang \\
\hline Kota Tangerang & 0,01 & 98,63 & 1 & 3 & 4 & Sedang \\
\hline Kota Cilegon & 0,05 & 97,55 & 3 & 3 & 6 & Tinggi \\
\hline Kota Serang & 0,03 & 96,61 & 2 & 3 & 5 & Tinggi \\
\hline Kota Tangsel & 0,01 & 97,35 & 1 & 3 & 4 & Sedang \\
\hline
\end{tabular}

Keterangan: (1) persentase jumlah taruna siaga bencana; dan (2) persentase bangunan rumah permanen/dinding tembok.

Berdasarkan data kapasitas pada Tabel 12 maka dapat dilihat bahwa terdapat 2 kota yang memiliki tingkat kapasitas tinggi, yaitu Kota Cilegon dan Serang. Selain itu, terdapat 4 kabupaten/ kota yang memiliki tingkat kapasitas sedang, yaitu Kabupaten Tangerang, Kabupaten Serang, Kota Tangerang, dan Kota Tangerang Selatan. Sisanya terdapat 2 kabupaten dengan tingkat kapasitas rendah, yaitu Kabupaten Pandeglang dan Lebak.

Tahapan selanjutnya setelah diketahui klasifikasi ancaman, kerentanan, dan kapasitas di setiap kabupaten/ kota yang ada di Provinsi Banten adalah melakukan penilaian risiko bencana. Penilaian risiko dilakukan berdasarkan komponen ancaman, kerentanan, dan kapasitas dengan menggunakan metode tabulasi silang.

\begin{tabular}{c|c|c|c}
\hline Rendah & $F, G$ & $H$ & Rendah \\
\hline Sedang & $C, D, E$ & & \\
\hline Tinggi & $A, B$ & & \\
\hline Keterangan: & $\begin{array}{l}A=\text { Kab. Pandeglang; } B=\text { Kab. Lebak; } \\
\text { C }\end{array}$ \\
& Kab. Tangerang; $D=$ Kab. Serang; \\
& $=$ Kota Tangerang; $F=$ Kota Cilegon; \\
& Tangerang Selatang; dan $H=$ Kota
\end{tabular}

Gambar 5. Matriks Ancaman $(\mathrm{H})$ - Kerentanan (V) Provinsi Banten

Berdasarkan Gambar 5 memperlihatkan bahwa dari matriks hubungan antara ancaman $(\mathrm{H})$ - kerentanan (V) diperoleh informasi terdapat 1 kota (Kota Tangerang Selatan) yang berada di tingkat rendah, 2 kota (Kota Cilegon dan Serang) berada di tingkat sedang, serta 5 kabupaten/ kota (Kabupaten Pandeglang, Kabupaten Lebak, Kabupaten Tangerang, Kabupaten Serang, dan Kota Tangerang) berada di tingkat tinggi.

\begin{tabular}{|c|c|c|c|}
\hline $\mathrm{C}_{\mathrm{C}} \mathrm{H}-\mathrm{V}$ & Tinggi & Sedang & Rendah \\
\hline Tinggi & & $F, G$ & \\
\hline Sedang & $C, D, E$ & & $H$ \\
\hline Rendah & $A, B$ & & \\
\hline & $\begin{array}{l}\quad A=K \\
\text { Lebak; } \\
\text { Kab. Sera } \\
F=\text { Kota } \\
\text { dan } H=K\end{array}$ & gon; $G$ & $\begin{array}{l}B=K a b \\
\text { rang; } D= \\
\text { angerang } \\
\text { ta Serang } \\
\text { Selatan }\end{array}$ \\
\hline
\end{tabular}

Gambar 6. Matriks Risiko Bencana Provinsi Banten

Berdasarkan Gambar 6 memperlihatkan bahwa dari matriks risiko bencana diperoleh informasi terdapat 3 kota (Kota Cilegon, Serang, dan Tangerang Selatan) yang berada di tingkat risiko rendah dan 5 kabupaten/kota (Kabupaten Pandeglang, Kabupaten Lebak, Kabupaten Tangerang, Kabupaten Serang, dan Kota Tangerang) berada di tingkat risiko tinggi.

\subsection{Perkembangan Wilayah di Provinsi Banten}

Perkembangan wilayah di Provinsi Banten dilakukan dengan memperkuat struktur internal tata ruang Provinsi Banten, yakni dengan memperkuat sistem kota-kota yang telah ada. Hal tersebut dilakukan dengan meningkatkan keterkaitan dan interaksi antar pusat-pusat pertumbuhan utama Provinsi Banten. Peluang interaksi langsung dengan wilayah luar tetap terbuka dan dimanfaatkan seoptimal mungkin. Selain tetap memperkuat struktur tata ruang internal, juga mulai memperkuat struktur tata ruang eksternal. Hal tersebut dicapai dengan mengembangkan kegiatan ekonomi wilayah yang diperkuat melalui pengembangan kegiatan industri dan pariwisata, sebagai simpul keterkaitan dengan wilayah Provinsi Banten, sehingga pada akhirnya dapat menciptakan keterkaitan (interaksi) ekonomi di antara kawasan-kawasan di Provinsi Banten yang mengarah pada integrasi 
ekonomi wilayah yang aman, nyaman, produktif, dan berkelanjutan (Bappeda Provinsi Banten, 2010).

Variabel dan indikator yang digunakan untuk menggambarkan tingkat perkembangan wilayah di Provinsi Banten dalam penelitian ini mengacu kepada Indikator Pembangunan Regional (BPS,
2011), seperti dapat dilihat pada Sub-bab 2.2 Tabel 3. Adapun kondisi perkembangan wilayah di Provinsi Banten dilihat dari 21 indikator pembangunan regional, berdasarkan data sekunder yang didapatkan dari BPS Provinsi Banten dapat dilihat pada Tabel 14.

Tabel 14. Perhitungan Indikator Perkembangan Wilayah Provinsi Banten

\begin{tabular}{c|c|c|c|c|c|c|c|c}
\hline \multirow{2}{*}{$\begin{array}{c}\text { Indikator } \\
\text { Nomor }\end{array}$} & \multicolumn{4}{|c}{ Kabupaten } & \multicolumn{4}{c}{ Kota } \\
\cline { 2 - 9 } & Pandeglang & Lebak & Tangerang & Serang & Tangerang & Cilegon & Serang & $\begin{array}{c}\text { Tangerang } \\
\text { Selatan }\end{array}$ \\
\hline 1.A.1) & 751.020 & 916.317 & 1.359 .893 & 1.051 .390 & 2.015 .135 & 1.575 .326 & 1.342 .302 & 1.993 .542 \\
\hline 1.A.2) & $28.323,94$ & $28.918,15$ & $141.088,31$ & $76.943,59$ & $175.237,82$ & $104.248,82$ & $31.765,21$ & $82.840,31$ \\
\hline 1.B.1) & 2,11 & 1,62 & 0,59 & 1,44 & 0,73 & 2,51 & 1,37 & 0,59 \\
\hline 1.B.2) & 91,29 & 91,95 & 91,09 & 89,35 & 92,87 & 90,32 & 91,92 & 95,21 \\
\hline 1.C.1) & $2.637,67$ & 334,72 & $2.806,54$ & 697,09 & $2.195,87$ & 637,80 & 185,04 & $1.817,51$ \\
\hline 2.A.1) & 94,15 & 93,48 & 95,70 & 94,84 & 96,71 & 97,41 & 95,29 & 98,33 \\
\hline 2.A.2) & 4,12 & 3,52 & 6,06 & 3,84 & 13,88 & 8,94 & 10,56 & 20,86 \\
\hline 2.A.3) & 83,89 & 70,88 & 88,03 & 81,58 & 91,15 & 91,11 & 79,86 & 93,78 \\
\hline 2.B.1) & 64,49 & 67,04 & 69,79 & 64,47 & 71,57 & 66,60 & 67,83 & 72,41 \\
\hline 2.C.1) & 0,54 & 0,83 & 3,24 & 0,76 & 2,35 & 1,68 & 1,91 & 3,36 \\
\hline 2.C.2) & 90,58 & 91,70 & 94,86 & 95,92 & 95,57 & 96,97 & 94,72 & 98,32 \\
\hline 3.A.1) & 0,66 & 0,64 & 0,35 & 0,47 & 0,29 & 0,39 & 0,34 & 0,26 \\
\hline 3.A.2) & 0,50 & 0,59 & 0,39 & 0,47 & 0,32 & 0,36 & 0,38 & 0,37 \\
\hline 3.A.3) & 0,39 & 0,39 & 0,31 & 0,39 & 0,29 & 0,31 & 0,28 & 0,28 \\
\hline 3.B.1) & 0,008 & 0,010 & 0,002 & 0,005 & 0,002 & 0,005 & 0,004 & 0,002 \\
\hline 3.B.2) & 85,2 & 91,6 & 106,1 & 93,4 & 90,1 & 96,5 & 95,3 & 99,9 \\
\hline 3.C.1) & 1,97 & 2,14 & 10,03 & 3,24 & 34,54 & 8,25 & 6,50 & 15,57 \\
\hline 4.A.1) & 6,79 & 5,27 & 12,31 & 10,78 & 20,37 & 15,68 & 17,96 & 31,12 \\
\hline 4.A.2) & 30,62 & 28,72 & 58,67 & 47,47 & 71,49 & 58,75 & 51,98 & 78,35 \\
\hline 4.B.1) & 0,29 & 0,36 & 0,69 & 0,52 & 1,23 & 0,75 & 0,5 & 2,14 \\
\hline 4.B.2) & 67,04 & 60,60 & 70,47 & 66,62 & 80,68 & 79,28 & 76,71 & 84,70 \\
\hline Sur.
\end{tabular}

Sumber: BPS Provinsi Banten (2020)

Keterangan: Nomor urut indikator mengacu pada penomoran indikator perkembangan wilayah pada Tabel 3.

Berdasarkan data indikator perkembangan wilayah Provinsi Banten yang tersaji pada Tabel 14 dapat dilakukan analisis menggunakan skoring, sehingga hasilnya dapat dilihat pada Tabel 15.

Tabel 15. Hasil Skoring Indikator Perkembangan Wilayah Provinsi Banten

\begin{tabular}{|c|c|c|c|c|c|c|c|c|}
\hline \multirow{2}{*}{$\begin{array}{c}\text { Indikator } \\
\text { ke- }\end{array}$} & \multicolumn{4}{|c|}{ Kabupaten } & \multicolumn{4}{|c|}{ Kota } \\
\hline & Pandeglang & Lebak & Tangerang & Serang & Tangerang & Cilegon & Serang & $\begin{array}{c}\text { Tangerang } \\
\text { Selatan }\end{array}$ \\
\hline 1.A.1) & 1 & 1 & 2 & 1 & 3 & 2 & 2 & 3 \\
\hline 1.B.1) & 3 & 2 & 1 & 2 & 1 & 3 & 2 & 1 \\
\hline 1.B.2) & 1 & 2 & 1 & 1 & 2 & 1 & 2 & 3 \\
\hline 1.C.1) & 3 & 1 & 3 & 1 & 3 & 1 & 1 & 2 \\
\hline 2.A.2) & 1 & 1 & 1 & 1 & 2 & 1 & 2 & 3 \\
\hline 2.A.3) & 2 & 1 & 3 & 2 & 3 & 3 & 2 & 3 \\
\hline 2.B.1) & 1 & 1 & 3 & 1 & 3 & 1 & 2 & 3 \\
\hline 2.C.1) & 1 & 1 & 3 & 1 & 2 & 2 & 2 & 3 \\
\hline 2.C.2) & 1 & 1 & 2 & 3 & 2 & 3 & 2 & 3 \\
\hline 3.A.1) & 3 & 3 & 1 & 2 & 1 & 1 & 1 & 1 \\
\hline 3.B.2) & 1 & 1 & 3 & 2 & 1 & 2 & 2 & 3 \\
\hline 3.C.1) & 1 & 1 & 1 & 1 & 3 & 1 & 1 & 2 \\
\hline 4.A.1) & 1 & 1 & 1 & 1 & 2 & 2 & 2 & 3 \\
\hline 4.A.2) & 1 & 1 & 2 & 2 & 3 & 2 & 2 & 3 \\
\hline 4.B.1) & 1 & 1 & 1 & 1 & 2 & 1 & 1 & 3 \\
\hline 4.B.2) & 1 & 1 & 2 & 1 & 3 & 3 & 3 & 3 \\
\hline Total & 33 & 31 & 39 & 31 & 44 & 37 & 36 & 50 \\
\hline
\end{tabular}




\begin{tabular}{c|c|c|c|c|c|c|c|c}
\hline \multirow{2}{*}{$\begin{array}{c}\text { Indikator } \\
\text { ke- }\end{array}$} & \multicolumn{4}{|c|}{ Kabupaten } & \multicolumn{4}{c}{ Kota } \\
\cline { 2 - 9 } & Pandeglang & Lebak & Tangerang & Serang & Tangerang & Cilegon & Serang & $\begin{array}{c}\text { Tangerang } \\
\text { Selatan }\end{array}$ \\
\hline Klasifikasi & Rendah & Rendah & Sedang & Rendah & Sedang & Sedang & Sedang & Tinggi \\
\hline
\end{tabular}

Sumber: Hasil Analisis Data, 2020

Berdasarkan data yang tersaji pada tabel 15 dapat dilihat bahwa terdapat 3 kabupaten (Pandeglang, Lebak, dan Serang) yang tingkat perkembangan wilayahnya masuk dalam klasifikasi rendah. Kabupaten/ kota yang tingkat perkembangan wilayahnya termasuk dalam klasifikasi sedang ada sebanyak 4, yaitu Kabupaten Tangerang, Kota Tangerang, Kota Cilegon, dan Kota Serang. Kota Tangerang Selatan menjadi satu-satunya kota di Provinsi Banten yang tingkat perkembangan wilayahnya termasuk dalam klasifikasi tinggi.

\subsection{Tipologi Hubungan Risiko Bencana dan Perkembangan Wilayah di Provinsi Banten}

Tipologi hubungan risiko bencana dan tingkat perkembangan wilayah disusun berdasarkan hasil klasifikasi dari masingmasing tingkat risiko bencana dan perkembangan wilayah pada tiap kabupaten/ kota di Provinsi Banten. Dari tipologi hubungan tersebut akan diketahui distribusi wilayah (kabupaten/ kota) berdasarkan hubungannya dan prioritas penanganan. Adapun hasil analisis tipologi hubungan risiko bencana dan perkembangan wilayah di Provinsi Banten dapat dilihat pada model integrasi hubungan (matriks) risiko bencana dan perkembangan wilayah seperti terlihat pada Gambar 7.

\begin{tabular}{|c|c|c|c|}
\hline \multirow{2}{*}{$\begin{array}{c}\text { Risiko } \\
\text { Bencana }\end{array}$} & \multicolumn{3}{|c|}{ Perkembangan Wilayah } \\
\hline & Tinggi & Sedang & Rendah \\
\hline Tinggi & & $C ; E$ & $A ; B ; D$ \\
\hline Sedang & & & \\
\hline Rendah & $H$ & $F ; G$ & \\
\hline Keterangan: & $\begin{array}{l}A=K a b . \\
C=K a b . \\
E=\text { Kota } \\
G=K o \\
\text { Tangeran }\end{array}$ & $\begin{array}{l}\text { ideglang; } E \\
\text { igerang; } D \\
\text { igerang; F } \\
\text { Serang; } d \\
\text { latan }\end{array}$ & $\begin{array}{l}\text { Kab. Lebak } \\
\text { Kab. Serang } \\
\text { Kota Cilegon } \\
H=\text { Kot }\end{array}$ \\
\hline
\end{tabular}

Gambar 7. Matriks Risiko Bencana dan Perkembangan Wilayah di Provinsi Banten

Berdasarkan data pada Gambar 7 dapat ditetapkan 4 tipologi hubungan risiko bencana dan perkembangan wilayah di Provinsi Banten mengacu kepada (Muta'ali, 2014), yaitu:

a. Wilayah dengan tingkat risiko bencana "tinggi" dan tingkat perkembangan wilayah "rendah", yang masuk dalam tipologi tersebut adalah Kabupaten Pandeglang,
Kabupaten Lebak, dan Kabupaten Serang.

b. Wilayah dengan tingkat risiko bencana "tinggi" dan tingkat perkembangan wilayah "sedang", yang masuk dalam tipologi tersebut adalah Kabupaten Tangerang dan Kota Tangerang.

c. Wilayah dengan tingkat risiko bencana "rendah" dan tingkat perkembangan wilayah "sedang", yang masuk dalam tipologi tersebut adalah Kota Cilegon dan Kota Serang.

d. Wilayah dengan tingkat risiko bencana "rendah" dan tingkat perkembangan wilayah "tinggi", yang masuk dalam tipologi tersebut adalah Kota Tangerang Selatan.

Sedangkan jika menggunakan pendapat Primandaru dan Suparno (2013), distribusi wilayah yang berisikan persebaran kabupaten/kota berdasarkan tingkat risiko bencana dan tingkat perkembangan wilayah menunjukkan tipologi hubungan dari kedua hal tersebut, dengan klasifikasi sebagai berikut:

a. Tipologi I merupakan Tipologi Tinggi, berisi wilayah yang mempunyai tingkat perkembangan wilayah "rendah" dengan tingkat risiko bencana "tinggi"; tingkat perkembangan wilayah "rendah" dengan tingkat risiko bencana "sedang"; dan tingkat perkembangan wilayah "sedang" dengan tingkat risiko bencana "tinggi". Tipologi ini membutuhkan pengembangunan wilayah paling utama (tinggi). Berdasarkan hasil analisis, wilayah di Provinsi Banten yang termasuk dalam tipologi I adalah Kabupaten Pandeglang, Kabupaten Lebak, Kabupaten Tangerang, Kabupaten Serang dan Kota Tangerang.

b. Tipologi II merupakan Tipologi Sedang, berisi wilayah yang memiliki tingkat perkembangan wilayah "rendah" dengan tingkat risiko bencana "rendah"; tingkat perkembangan wilayah "sedang" dengan tingkat risiko bencana "sedang"; dan tingkat perkembangan wilayah "tinggi" dengan tingkat risiko bencana "tinggi". Tipologi ini membutuhkan pengembangan wilayah setelah tipologi I. Berdasarkan hasil analisis, tidak ada wilayah di Provinsi Banten yang termasuk dalam tipologi II.

c. Tipologi III merupakan Tipologi Rendah, berisi wilayah yang memiliki tingkat 
perkembangan wilayah "sedang" dengan tingkat risiko bencana "rendah"; tingkat perkembangan wilayah "tinggi" dengan tingkat risiko bencana "sedang"; dan tingkat perkembangan wilayah "tinggi" dengan tingkat risiko bencana "rendah". Tipologi ini membutuhkan pengembangan wilayah setelah tipologi II. Berdasarkan hasil analisis, wilayah di Provinsi Banten yang termasuk dalam tipologi III ini adalah Kota Cilegon, Kota Serang, dan Kota Tangerang Selatan.

\section{KESIMPULAN}

Berdasarkan hasil kajian yang sudah dilakukan dapat disimpulkan antara lain:

a. Tingkat risiko bencana di Provinsi Banten terbagi menjadi 2, yaitu tingkat risiko tinggi, dimana terdapat 5 kabupaten/kota di dalamnya (Kabupaten Pandeglang, Kabupaten Lebak, Kabupaten Tangerang, Kabupaten Serang, dan Kota Tangerang), serta tingkat risiko rendah dimana terdapat 3 kota di dalamnya (Kota Cilegon, Kota Serang, dan Kota Tangerang Selatan).

b. Tingkat perkembangan wilayah di Provinsi Banten terbagi menjadi 3, yaitu tingkat perkembangan wilayah rendah, dimana terdapat 3 kabupaten di dalamnya (Kabupaten Pandeglang, Kabupaten Lebak, dan Kabupaten Serang). Tingkat perkembangan wilayah sedang, dimana terdapat 4 kabupaten/ kota di dalamnya (Kabupaten Tangerang, Kota Tangerang, Kota Cilegon, dan Kota Serang). Terakhir adalah tingkat perkembangan wilayah tinggi, dimana hanya Kota Tangerang Selatan saja yang ada di dalamnya.

c. Perkembangan wilayah di Provinsi Banten berdasarkan hasil hubungan risiko bencana dan perkembangan wilayah terbagi menjadi 4 tipologi (menggunakan referensi Muta'ali tahun 2014), serta terbagi menjadi 2 tipologi (menggunakan referensi Primandaru dan Suparno tahun 2013), yaitu tipologi I (tinggi) dan tipologi III (rendah).

\section{DAFTAR PUSTAKA}

Alkadri. 2011. Kebijakan Pengembangan Kawasan Ekonomi Khusus (KEK) di Provinsi Banten. Jurnal Sains dan Teknologi Indonesia. Vol 13, No. 1, April 2011: 7-13.

Bappeda Provinsi Banten. 2005. Rencana Pembangunan Jangka Panjang Provinsi Banten Tahun 2005 - 2025. Serang.
Bappeda Provinsi Banten. 2010. Rencana Tata Ruang Wilayah Provinsi Banten 2010 2030. Serang.

BLHD Provinsi Banten. 2015. Kajian Penetapan Ekoregion Provinsi Banten. Serang.

BNPB. 2015. Kajian Risiko Bencana Banten 2016 - 2020. Deputi Bidang Pencegahan dan Kesiapsiagaan BNPB. Jakarta.

BPS. 2011. Indikator Pembangunan Regional. Jakarta.

BPS Provinsi Banten. 2019. Statistik Kesejahteraan Rakyat Provinsi Banten 2019. Serang.

BPS Provinsi Banten. 2020. Provinsi Banten dalam Angka 2020. Serang.

BPS Provinsi Banten. 2020. Statistik Daerah Provinsi Banten 2020. Serang.

Muta'ali, L. 2014. Perencanaan Pengembangan Wilayah Berbasis Pengurangan Risiko Bencana. BPFG UGM. Yogyakarta.

Nazir, M. 1988. Metode Penelitian. Ghalia Indonesia. Bogor.

Peraturan Daerah Provinsi Banten Nomor 3 Tahun 2010 tentang Badan Penanggulangan Bencana Daerah Provinsi Banten.

Peraturan Menteri Sosial RI Nomor 128 Tahun 2011 tentang Kampung Siaga Bencana.

Primandaru, N dan Suparno, U.R. 2013. Pengembangan Wilayah Berbasis Risiko Bencana di Kabupaten Klaten. Magister Manajemen Bencana UGM. Yogyakarta.

Soleman, M.K., Nurcahyani, F., dan Munajati, S.L. 2012. Pemetaan Multirawan Bencana di Provinsi Banten. Globe. Vol. 14, No. 1, Juni 2012: 46-59.

Sudibyakto dan Priatmodjo, A. 2016. Manajemen Risiko Bencana pada Kawasan Cagar Budaya Gunung Padang, Ciamis, Jawa Barat. Jurnal Riset Kebencanaan Indonesia. Vol. 2, No. 1. Mei 2016: 50-58.

Undang-Undang Nomor 23 Tahun 2000 tentang Pembentukan Provinsi Banten.

Wijono, R.S. 2017. Di bawah Bayang-bayang Ibu Kota: Penataan Daerah di Provinsi Banten dari Zaman Kolonial Sampai Zaman Reformasi. Jurnal Sejarah Citra Lekha. Vol. 2, No. 2, 2017: 126-142. 